\title{
The Fruit Characteristics of Ambon Forest Nutmeg (Myristica fatua Houtt) and Banda Nutmeg (Myristica fragrans Houtt)
}

\section{(Perbandingan Komposisi Kimia dan Kadar Minyak Atsiri Buah Pala Hutan Ambon (Myristica fatua Houtt) dan Banda (Myristica fragrans Houtt))}

\author{
Karmanah $^{1,2}$, Slamet Susanto ${ }^{3 \star}$, Winarso Drajad Widodo ${ }^{3}$, Edi Santosa ${ }^{3}$
}

(Diterima Oktober 2019/Disetujui Maret 2020)

\begin{abstract}
Ambon Forest nutmeg (Myristica fatua Houtt) is one of the endemic plants in Indonesia. The morphological characteristic of Ambon Forest nutmeg is slightly different from that of Banda nutmeg (Myristica fragrans Houtt) i.e., it is not used as spices, but its oil is used as a lamp oil. This study aimed to determine the chemical components and essential oils of Ambon Forest nutmeg derived from its seeds, mace, and flesh compared to Banda nutmeg. Extractions of essential oils were performed using a steam hydro-distillation. Analysis of chemical compositions and contents of essential oil was carried out using a Gas Chromatography-Mass Spectrometry (GCMS) instrument and SNI 06-2388-2006 method. The essential oil contents in Ambon Forest nutmeg were relatively low, i.e., $0.63 \%$ in the seeds, $0.30 \%$ in the mace, and $0.04 \%$ in the flesh compared to Banda nutmeg i.e., $1 \%$ in the seeds, $40 \%$ in the mace, and $3.5 \%$ in the fruit flesh. The chemical compositions of essential oils showed that $\boldsymbol{M}$. fatua Houtt contained 12 compounds in the seeds, 24 compounds in the mace, and 17 compounds in the fruit flesh, while for Banda Nutmeg, the contents of essential oils were found 18 compounds in the seeds, 10 compounds in the mace, and 15 compounds in the fruit flesh. M. fatua Houtt contained the highest Copaene, i.e., $28.41 \%$ in the seeds, $10.42 \%$ in the mace, and 23.33\% in the fruit flesh. Myristicin, as the main marker compound of nutmeg oil, was also found in Ambon Forest nutmeg i.e., $1.3 \%$ in the seeds, $1.16 \%$ in the mace, and $5.19 \%$ in the fruit flesh. However, these results showed lower contents when compared to Banda nutmeg with Myristicin contents of $8.72 \%$ in the seeds, $10.14 \%$ in the mace, and $10.46 \%$ in the fruit flesh.
\end{abstract}

Keywords: Essential oil, Myristica fatua Houtt, Myristica fragrans Houtt, Nutmeg

\section{ABSTRAK}

Pala Hutan Ambon (Myristica fatua Houtt) merupakan salah satu spesies pala endemik di Indonesia. Secara morfologi, pala ini sedikit berbeda dari pala Banda (Myristica fragrans Houtt), yaitu tidak digunakan sebagai rempah, namun minyaknya digunakan untuk minyak lampu. Penelitian bertujuan untuk mengetahui komposisi kimia dan minyak atsiri pala Hutan Ambon yang berasal dari biji, fuli, dan daging buah serta dibandingkan dengan pala Banda. Ekstraksi minyak atsiri dilakukan dengan cara destilasi uap air. Analisis komposisi kimia minyak atsirinya dilakukan menggunakan instrumen Gas Chromatography-Mass Spectrometry (GCMS). Metode analisis komposisi kimia minyak atsiri dilakukan berdasarkan SNI 06-2388-2006. Hasil analisis kadar minyak atsiri biji pala Hutan Ambon adalah sebesar $0,63 \%$, fuli sebesar $0,30 \%$, dan daging buah sebesar $0,04 \%$, yang lebih rendah dibandingkan dengan pala Banda, yaitu pada biji sebesar $1 \%$, fuli sebesar $40 \%$, dan daging buah sebesar $3.5 \%$. Komposisi kimia minyak atsiri pala Hutan Ambon teridentifikasi sebanyak 12 senyawa dari minyak biji pala, 24 senyawa dari fuli, dan 17 senyawa dari daging buah, sementara pala Banda mengandung sebanyak 18 senyawa di biji, 10 senyawa di fuli, dan 17 senyawa di daging buah. Pala Hutan Ambon menghasilkan senyawa Copaene yang kandungannya paling tinggi dibandingkan dengan senyawa lainnya, yaitu di dalam biji sebanyak $28,41 \%$, fuli sebanyak $10,42 \%$, dan pada daging buah sebanyak $23,33 \%$. Myristicin, sebagai senyawa penciri utama pada minyak pala, ditemukan pada pala hutan Ambon dengan kandungan di dalam biji sebesar 1,30\%, fuli sebesar $1,16 \%$, dan pada daging buah sebesar $5,19 \%$, namun hasilnya juga tergolong rendah dibandingkan dengan pala Banda dengan kandungan di dalam biji sebesar $8,72 \%$, fuli sebesar $10,14 \%$, dan daging buah sebesar $10,46 \%$.

Kata kunci: Minyak atsiri, Myristica fatua Houtt, Myristica fragrans Houtt, Pala

1 Graduate School, Department of Agronomy and Horticulture, Faculty of Agriculture, IPB University, IPB Darmaga Campus, Bogor 16680

2 Faculty of Agriculture, Nusa Bangsa University, Jl. KH Sholeh Iskandar Km. 4, Tanah Sareal, Bogor 16166

3 Department of Agronomy and Horticulture, Faculty of Agriculture, IPB University, IPB Darmaga Campus, Bogor 16680

* Correspondence Writer: Email: slmtsanto@gmail.com

\section{INTRODUCTION}

Ambon Forest nutmeg (Myristica fatua Houtt) is one of the endemic nutmeg species found in Indonesia, especially in the Maluku region (Lim 2012; Fajriah et al. 2017). Physically, the size of $M$. fatua Houtt nutmeg is slightly larger than that of Banda nutmeg $(M$. fragrans Houtt) and the surface of the fruit skin is coated by 
powder (like flour) (De Wild 2000). The fruits are not used as herbs, but traditionally the fruits are often used as an aphrodisiac drug, and the oil is used as a lamp oil (Heyne 1987). Ambon Forest nutmeg is in one family with Banda nutmeg, but it is not as well-known as Banda nutmeg and there are not many researches that describe the chemical components and contents of essential oils in this species so that its benefits are unrevealed as a spice or as a flavor. Fajriah \& Megawati (2015) study reported that the ethyl acetate fraction of the extract of $M$. fatua leaves showed a high toxicity and indicated its potential to be developed as an anticancer drug. Therefore, research on the chemical composition and content of essential oils of Ambon Forest nutmeg (Myristica fatua Houtt) needs to be conducted to investigate whether the Ambon Forest nutmeg can be optimally utilized as the Banda nutmeg.

Banda nutmeg (Myristica fragrans Houtt) is a commercial-spice crop in the forms of seeds and mace which is the main commodity in the world-spice trade. This plant produces essential oils which are used for health and as a flavor. Pal et al. (2011) reported that the main components in essential oil of $M$. fragrans Houtt are sabinene, myristicin, safrole, elemicin, $\alpha$ pinene, $\beta$-pinene, and camphene. The results of the other studies indicated that the chemical content of nutmeg-seed extract in the form of essential oils and oleoresin had been widely used in various applications of food as a flavor agent such as in milk-based drinks production, food based on animal meat, as well as in the health and beauty products such as aroma therapy, perfume, toothpaste, and in traditional medicine (Assagaf et al. 2012).

According to Smith (2014), nutmeg essential oil contains $5-15 \%$ of volatile oil. Volatile oil consists of monoterpenic hydrocarbons ( $80 \%)$, alcohol $(5 \%)$, and aromatic fractions of ether (myristicin, elemicin, safrole, methyleugenol, eugenol, isoeugenol, and toluene) and the other groups of compounds. Myristicin is the most important component, which is found of almost $4-12 \%$ in essential oils. The hallucinogenic myristicin component has been reported to be used as an effective insecticide and has a toxic effect on pests ( $\mathrm{Pal}$ et al. 2011). According to Shafiq et al. (2016), nutmeg essential oil has a broad spectrum of antifungal and is potential as a long-term inhibitor so that it is recommended to be used in antifungal drug formulations as well as in food preservation. This study aimed to determine the chemical components and essential oils of Ambon Forest nutmeg derived from its seeds, mace, and flesh and are compared to Banda nutmeg.

\section{MATERIALS AND METHODS}

\section{Study Area}

The materials used were the Ambon Forest nutmegs from Morella region in Ambon Island, Indonesia. The area is located at the coordinates of $3^{\circ} 31^{\prime} 11.4^{\prime \prime}$ South latitude and 128 $13^{\prime} 15.6^{\prime \prime}$ East longitude at a height of $47.6 \mathrm{~m}$ above sea level. Banda nutmegs were obtained from nutmeg farmers in the Ambon region which is located at $3^{\circ} 32^{\prime} 37.9^{\prime \prime}$ South latitude and $128^{\circ} 12^{\prime} 48.0^{\prime \prime}$ East longitude. The collected nutmegs were then separated by the seeds, mace, and fruit flesh.

\section{Research Procedures \\ - Identification of nutmeg species}

The identification of nutmeg species was performed at the "Herbarium Bogoriense", Botany Division of the Biology Research Center, the Indonesian Institute of Sciences, Bogor, to clearly identify the identity of collected Ambon Forest and Banda nutmeg samples.

\section{- Essential oils extraction}

Extractions of nutmeg essential oils from seeds, mace, and fruit flesh of Ambon Forest nutmeg were carried out in the essential oil distillation unit of the Indonesian Spices and Medicinal Plants Research Institute (BALITTRO), Bogor using the water steam distillation method. The method used in the distillation of nutmeg oil followed the method of Ketaren (1987), with the stages of analysis as follows: The cleaned material was dried for two weeks to reduce the water content of the material to about $10-15 \%$. As much as $200 \mathrm{~g}$ of material was chopped by a chopper machine into small pieces that pass the filter size about $0.5 \mathrm{~cm}^{2}$. As much as $50 \mathrm{~g}$ of the sample was taken for determination of water content before distillation. The chopped material was put into a distillation flask then water was added to a volume of 1 liter. The flask was boiled at a temperature of $100^{\circ} \mathrm{C}$ for 10 to 12 hours until all oil in the material was extracted. The extracted nutmeg oil was separated from distilled water using anhydrous sodium sulfate $\left(\mathrm{NA}_{2} \mathrm{SO}_{4}\right)$ and then it was filtered to obtain pure nutmeg essential oil. The extracted oil was then measured for its oil content, and its chemical component was also analyzed.

\section{- Chemical components analysis of essential oils}

Chemical component analysis of essential oils was performed using a gas chromatography and mass spectrometry (GCMS) instrument of Agilent Technologies 7890 with auto sampler and 5975 Mass Selective Detector and Chemstation data analysis system. The chemical components analysis of essential oils was carried out based on the chemical components analysis of essential oils of Indonesian National Standard (SNI) 06-2388-2006. The analysis was conducted at the Regional Health Laboratory, Jakarta.

The operating conditions of the gas chromatography instrument were as follows: HP Ultra 2 column was equipped with a capillary column length of $30 \mathrm{~m}$, an internal diameter of $0.20 \mathrm{~mm}$ with a film thickness of $0.11 \mu \mathrm{m}$. Programmed column temperature was from $140-280^{\circ} \mathrm{C}$ with an increase of $1.2 \mathrm{ml} / \mathrm{min}$, injector temperature of $250^{\circ} \mathrm{C}$, the mobile 
gas was Helium with a flow rate of $1.2 \mathrm{~mL} / \mathrm{min}$, the detector type was a flame ionization, with a sample volume of $5 \mu \mathrm{l}$ and split ratio of $8: 1$.

\section{Data Analysis}

Calculation of the concentration of each oil component was determined by calculating the peak area percentage of each component of the total peak area on the chromatogram expressed in percentage. An authentic mass spectrum library from the National Institute Standard of Technology (NIST) was used as a standard to identify the spectrum of each peak in the chromatogram. Data analysis of the chemical components of essential oils was performed using $R$ Stat 3.1.0 software to generate a heatmap profile for the classification of essential oils.

\section{RESULTS AND DISCUSSION}

\section{Nutmeg Species Identification}

The identification results of the two nutmeg samples showed that $M$. fatua Houtt belongs to the Myristicaceae family with the code L1227 PHS and it was in one family with the Banda nutmeg (Myristica fragrans Houtt) (the Indonesian Institute of Sciences, 2019). The morphologies of Ambon Forest nutmeg and Banda nutmeg are shown in Figure 1.

Based on Figure 1, it was visually observed that Ambon Forest nutmeg and Banda nutmeg had morphological similarities where each fruit consisted of three parts, i.e., fruit flesh, seeds consisting of shell and mace, but based on some morphological characteristics of fruit, seeds, and mace, Ambon Forest nutmeg was different from Banda nutmeg (Table 1). Ambon forest nutmeg fruits were larger in size with a powder coated skin (similar to flour/coated powder), while Banda nutmeg fruits had a slick skin. Another difference was that the fruit flesh taste was astringent not like the taste of nutmeg fruit flesh which was generally spicy, and the size of the seeds was bigger but both the seeds and the mace did not have a typical nutmeg aroma.

\section{Essential Oils Extraction}

Figure 2 shows the essential oil contents from the extraction of three parts of Ambon Forest nutmeg which are the seeds, mace, and fruit flesh.

The results showed that the essential oil contents of seed, mace, and fruit flesh of Ambon Forest nutmeg were 0.63 ; 0.30 ; and $0.04 \%$, respectively (Figure 2). The essential oil contents of Ambon Forest nutmeg were different when compared to Banda nutmeg, in which the essential oil contents of the three parts of Ambon Forest nutmeg were relatively low although the water content of the analyzed material was relatively the same, which was in the range of $6-8 \%$. The study of Jamal \& Agusta (2004) showed different results that M. fatua Houtt essential oil content obtained from mace was $0.81 \%$ and seed was $0.73 \%$. These results also indicated that $M$. fatua Houtt essential oil contents were still low when compared to essential oils of Banda nutmeg. The difference in these analytical results of essential oil contents with the research carried out was due to the analyzed fruit sources originated from different plants and environments. Differences in essential oil contents are influenced not only by plant genetic factors but also by environmental factors (Figueiredo et al. 2008; Ma'mun 2013). Both of the results in this study indicated that the M. fatua Houtt essential oil content was still relatively low when compared to the essential oil contents in the seeds and mace of the Banda nutmeg fruit. The low content of these essential oils causes the aromas of the seeds and mace of Ambon forest nutmeg to be less strong.

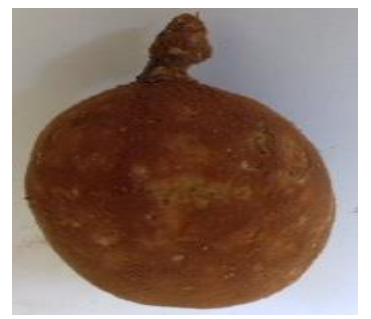

A

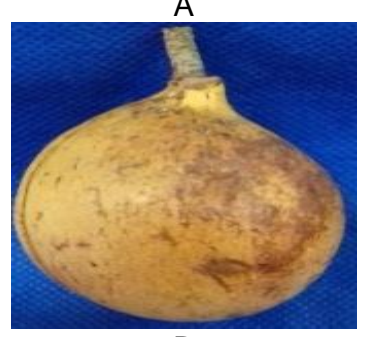

B

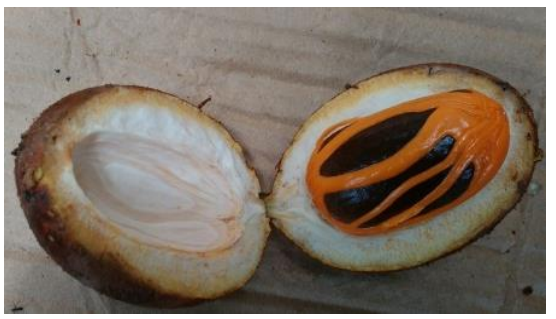

A1

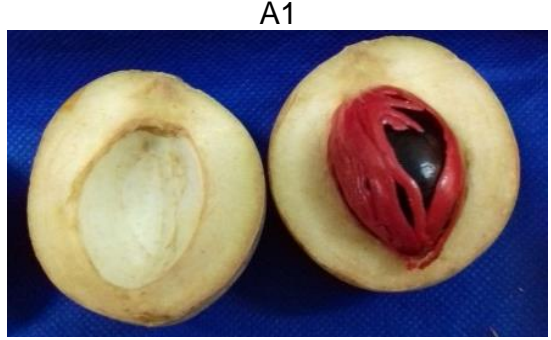

B1

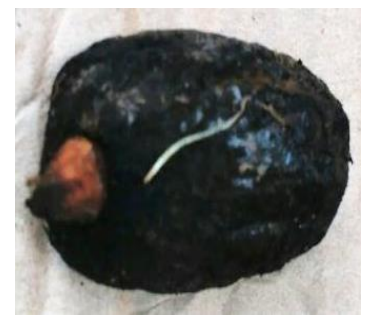

A2

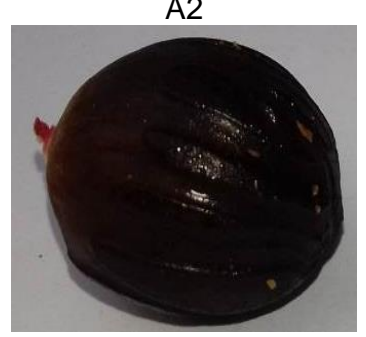

B2
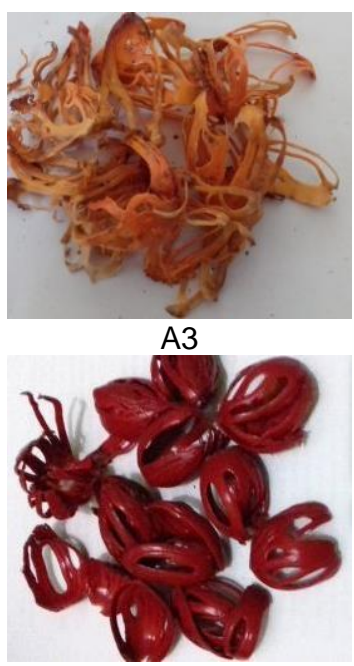

B3

Figure 1 A Ambon Forest nutmeg and its parts of fruit flesh (A1), seeds (A2), and mace (A3); B. Banda nutmeg and its parts of fruit flesh (B1), seeds (B2), and mace (B3). 
Table 1 Morphological characters of fruit, seeds and mace of Ambon Forest nutmeg (Myristica fatua) and Banda nutmeg (Myristica fragrans)

\begin{tabular}{lll}
\hline \multicolumn{1}{c}{ Character } & \multicolumn{1}{c}{ Myristica fatua } & Myristica fragrans \\
\hline Fruit skin color & Orange brownish & Yellow brownish \\
Skin surface of the fruit & Coated powder & Slick \\
Fruit Flesh Color & White & Milky white \\
Taste fruit flesh & Astringent & Spicy \\
Average fruit weight per item (g) & 97 & 46.8 \\
Fruit shape & Oblong (ID=1.4) & Oval (ID =1.18) \\
Flavour of fruits & Not necessarily & Fragrant (Typical nutmeg) \\
Colour of mace & Orange gray & Blood red \\
Taste of mace & Spicy & Spicy \\
Flavour of mace & Not necessarily & Fragrant (Typical nutmeg) \\
Closure of mace (\%) & 25 & 87 \\
Average fruit gross weight per item (g) & 1.45 & 1.81 \\
Colour of seed shell & Shiny black & Blackish brown \\
Avarage seed weight per item $(\mathrm{g})$ & 22.50 & 9.93 \\
Seeds shape (ID) & Oblong (ID=1.61) & Oval (ID =1.16) \\
\hline
\end{tabular}

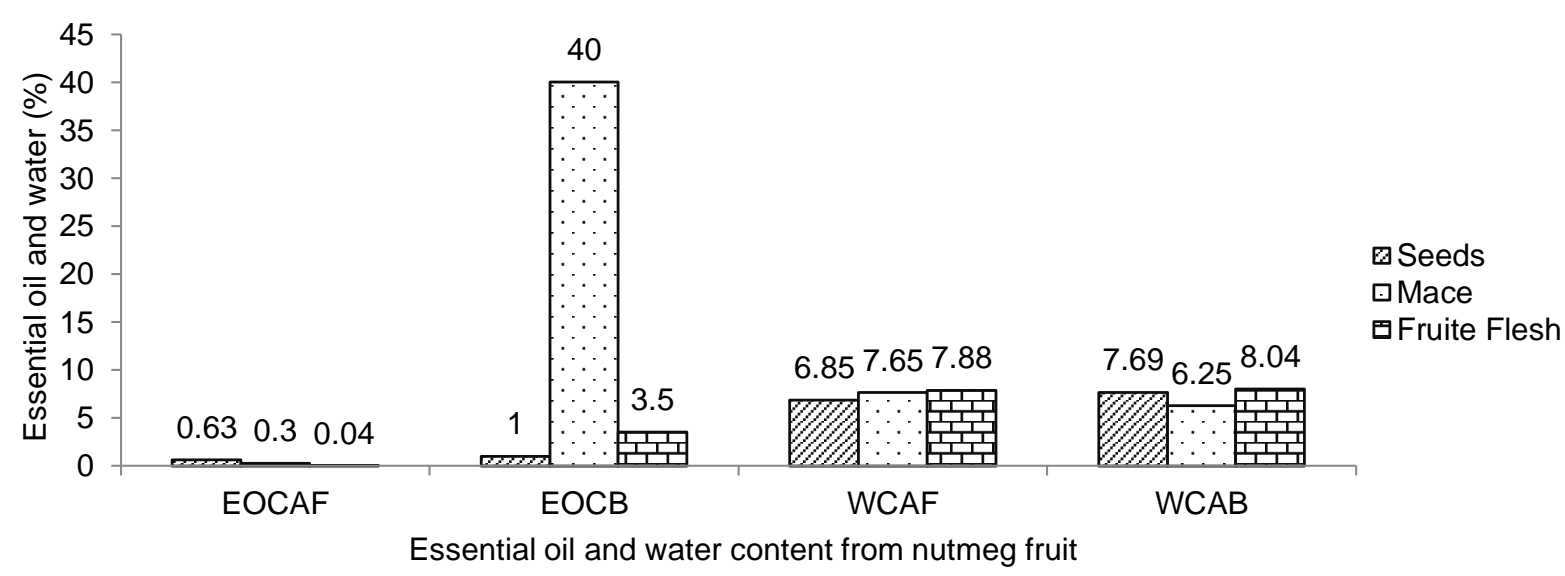

Figure 2 Essential oil contents (EOC) and water contents (WC) of Ambon Forest (AF) and Banda (B) nutmegs.

The aroma and taste of nutmeg seeds and mace are the main components in their use as spices.

\section{Chemical Components Analysis of Essential Oils}

The results of GCMS analysis of the chemical components of essential oils from seeds, mace, and fruit flesh of Ambon Forest nutmegs are shown in Table 2. The essential oil chemical components of Ambon Forest nutmeg seed consisted of 12 compounds, mace essential oil consisted of 24 compounds, and fruit flesh oil consisted of 17 compounds. There were three chemical compounds found in the seeds, mace, and fruit flesh of Ambon Forest nutmeg, i.e., Copaene, Caryophyllene, and Myristicin compounds. The results showed that the contents of Copaene in the three parts of nutmeg were the highest compared to the other compounds, with the content in the seeds was $28.41 \%$, in the mace was $10.42 \%$, and in the fruit flesh was $23.33 \%$. Copaene or $\alpha$-copaene compounds with the chemical formula $\mathrm{C}_{15} \mathrm{H}_{24}$, are tricyclic sesquiterpenes found in several different plants, including Ceratitis capitata (Nishida et al. 2000), Cedrelopsis grevei (Afoulous et al. 2013), and Xylopia laevigata (Quintans et al. 2013).
Several studies on a-copaene in essential oils indicated that $\alpha$-copaene compounds had anticarcinogenic, antioxidant, hepatoprotective, and antiinflammatory activities (Vinholes et al. 2013). The results of the other studies revealed that $\alpha$-copaene had important biological activities including as antigenotoxic and antioxidant (Turkez et al. 2013), $\alpha-$ copaene also had a potential as an anticancer agent that required further studies (Turkez et al. 2014). Caryophyllene compound is one of the main components of essential oils from seeds, mace, and fruit flesh of Ambon Forest nutmeg each with content of $38.13 \%$ in seeds, $10.31 \%$ in mace, and $3.05 \%$ in fruit flesh. Caryophyllene compounds have biological activities, such as antibacterial, anti-asthma, antiinflammatory, and are used as a flavor in perfumes and fungicides productions (Jamal \& Agusta 2004).

Results of GCMS analysis showed the identified essential oil chemical components in the Banda nutmeg were 18 chemical compounds in the seed, 10 compounds in the mace, and 15 compounds in the fruit flesh (Table 3). The analytical results showed that the oil of seeds, mace, and fruit flesh of Banda nutmeg were dominated by the monoterpene group. In total, 
Table 2 Component and concentration of essential oils from seeds, mace, and fruit flesh of Ambon Forest nutmeg (Myristica fatua Houtt)

\begin{tabular}{|c|c|c|c|c|c|c|c|c|c|c|c|c|c|c|}
\hline \multicolumn{5}{|c|}{ Seeds Oil } & \multicolumn{5}{|c|}{ Mace Oil } & \multicolumn{5}{|c|}{ Flesh Oil } \\
\hline Component $^{1}$ & Class $^{2}$ & Conc $(\%)^{3}$ & $\mathrm{RT}^{4}$ & $Q^{5}$ & Component $^{1}$ & Class $^{2}$ & Conc $(\%)^{3}$ & $\mathrm{RT}^{4}$ & $Q^{5}$ & Component $^{1}$ & Class $^{2}$ & Conc $(\%)^{3}$ & $\mathrm{RT}^{4}$ & $Q^{5}$ \\
\hline Caryophyllene & $\mathrm{s}$ & 38.13 & 29.156 & 99 & Caryophyllene & $\mathrm{s}$ & 10.31 & 29.001 & 99 & Caryophyllene & $\mathrm{s}$ & 3.05 & 29.001 & 99 \\
\hline Myristicin & A & 1.30 & 51.964 & 99 & Myristicin & A & 1.16 & 51.964 & 99 & Myristicin & A & 5.19 & 51.965 & 99 \\
\hline Copaene & s & 28.41 & 23.757 & 99 & Copaene & s & 10.42 & 23.647 & 99 & Copaene & s & 23.33 & 23.704 & 98 \\
\hline Germacrene D & s & 2.69 & 34.854 & 98 & Germacrene D & $\mathrm{s}$ & 1.95 & 40.868 & 99 & Curcumene & $\mathrm{s}$ & 3.96 & 8.268 & 98 \\
\hline Guaiol & A & 1.35 & 49.406 & 99 & Guaiol & A & 5.28 & 49.406 & 99 & D-Limonene & $\mathrm{s}$ & 4.97 & 9.363 & 99 \\
\hline $\begin{array}{l}\text { Gamma- } \\
\text { Elemene }\end{array}$ & s & 1.77 & 22.344 & 98 & Curcumene & s & 7.36 & 38.287 & 99 & $\begin{array}{l}\text { Beta- } \\
\text { Phellandrene }\end{array}$ & M & 15.78 & 9.711 & 91 \\
\hline Beta-Copaene & s & 2.20 & 25.963 & 99 & Beta-curcumene & s & 7.91 & 36.782 & 99 & o-Cymene & M & 2.58 & 12.039 & 97 \\
\hline Humulene & s & 4.97 & 32.778 & 97 & Cis-muurole-3,5-diene & s & 2.00 & 37.568 & 97 & Linalool & M & 11.97 & 25.868 & 96 \\
\hline Germacrene B & s & 3.25 & 40.887 & 99 & Eugenol & PP & 2.72 & 50.440 & 98 & Eugenol & PP & 4.52 & 50.435 & 98 \\
\hline Aromandendrene & $\mathbf{s}$ & 1.15 & 51.487 & 91 & Curzerane & $\mathrm{s}$ & 1.66 & 42.897 & 98 & $\begin{array}{l}\text { Alpha- } \\
\text { Terpineol }\end{array}$ & M & 1.34 & 33.740 & 86 \\
\hline Alpha-Cubenene & s & 2.42 & 21.816 & 99 & Caryophyllene oxide & $\mathrm{s}$ & 1.07 & 47.430 & 74 & $\begin{array}{l}\text { Alpha- } \\
\text { Cubenene }\end{array}$ & $\mathrm{s}$ & 1.66 & 21.811 & 99 \\
\hline \multirow[t]{13}{*}{$\begin{array}{l}\text { Gamma- } \\
\text { Cadinene }\end{array}$} & s & 4.04 & 37.582 & 98 & Nerolidol & s & 1.21 & 48.759 & 74 & $\begin{array}{l}\text { Gamma- } \\
\text { Cadinene }\end{array}$ & s & 3.10 & 37.568 & 98 \\
\hline & & & & & $\begin{array}{l}\text { Napthalene, 1,2,2,4,4a,7- } \\
\text { hexahydro-1,6-dimethyl- } \\
\text { 4-(1-methylethyl)- }\end{array}$ & A & 1.58 & 49.054 & 95 & $\begin{array}{l}\text { 2-(4a,8- } \\
\text { Dimethyl- } \\
2,3,4,5,6,8 \mathrm{a}- \\
\text { hexahydro- } \\
1 \mathrm{H} \text { - } \\
\text { naphthalen-2- } \\
\text { yl) propan-2- } \\
\text { ol }\end{array}$ & A & 1.03 & 51.487 & 58 \\
\hline & & & & & Spathulenol & PP & 1.61 & 49.864 & 95 & $\begin{array}{l}\text { 2- } \\
\text { Undecanone }\end{array}$ & $\mathrm{s}$ & 2.87 & 28.730 & 90 \\
\hline & & & & & Gurjunene & s & 1.12 & 50.254 & 96 & Zingiberene & $\mathrm{s}$ & 4.28 & 35.763 & 95 \\
\hline & & & & & Cis-Thujospsene & $\mathrm{s}$ & 1.13 & 50.330 & 43 & $\begin{array}{l}\text { Beta- } \\
\text { Bisabolene }\end{array}$ & $\mathrm{s}$ & 2.14 & 36.092 & 91 \\
\hline & & & & & Germacrene D & $\mathbf{s}$ & 3.61 & 50.606 & 94 & Tumerone & $\mathrm{s}$ & 2.06 & 50.697 & 98 \\
\hline & & & & & Beta-elemenone & $\mathrm{s}$ & 4.26 & 50.683 & 64 & & & & & \\
\hline & & & & & Beta-elemenone & s & 5.05 & 50.825 & 95 & & & & & \\
\hline & & & & & Beta-elemenone & $\mathrm{s}$ & 2.50 & 50.987 & 96 & & & & & \\
\hline & & & & & Epicurzerenone & s & 15.10 & 51.164 & 99 & & & & & \\
\hline & & & & & Cadinene & $\mathrm{s}$ & 2.98 & 51.330 & 93 & & & & & \\
\hline & & & & & Alpha-Patchoulene & $\mathrm{s}$ & 4.70 & 51.487 & 74 & & & & & \\
\hline & & & & & aR-Turmerone & $\mathrm{s}$ & 2.48 & 51.830 & 53 & & & & & \\
\hline
\end{tabular}

Description: ${ }^{1}$ Component of GC-MS analysis, ${ }^{2} \mathrm{~S}=$ Sesquiterpenoids, $\mathrm{PP}=$ Phenylpropanoids, $\mathrm{A}=\mathrm{Alipatichs,} \mathrm{M}=$ Monoterpenoids, ${ }^{3}$ Concentration of component, ${ }^{4}$ Retention time, and ${ }^{5}$ Quality.

Table 3 Component and concentration of essential oils from seeds, mace, and fruit flesh of Banda nutmeg (Myristica fragrans Houtt)

\begin{tabular}{|c|c|c|c|c|c|c|c|c|c|c|c|c|c|c|}
\hline \multirow[b]{2}{*}{ Component ${ }^{1}$} & \multicolumn{3}{|c|}{ Seeds Oil } & \multirow[b]{2}{*}{$Q^{5}$} & \multicolumn{5}{|c|}{ Mace Oil } & \multicolumn{5}{|c|}{ Flesh Oil } \\
\hline & Class $^{2}$ & Conc $(\%)^{3}$ & $\mathrm{RT}^{4}$ & & Component ${ }^{1}$ & Class $^{2}$ & Conc $(\%)^{3}$ & $\mathrm{RT}^{4}$ & $Q^{5}$ & Component ${ }^{1}$ & Class $^{2}$ & Conc $(\%)^{3}$ & $\mathrm{RT}^{4}$ & $Q^{0}$ \\
\hline Alpha-pinene & $\mathrm{M}$ & 7.8 & 4.911 & 96 & Alpha-pinene & M & 10.51 & 4.911 & 96 & Alpha-pinene & M & 7.14 & 4.906 & 96 \\
\hline Beta-pinene & M & 10.37 & 6.715 & 97 & Beta-pinene & M & 8.34 & 6.706 & 97 & Beta-pinene & M & 5.30 & 6.706 & 97 \\
\hline Myristicin & A & 8.72 & 51.964 & 99 & Myisticin & A & 10.14 & 51.964 & 99 & Myristicin & A & 10.46 & $\begin{array}{l}51.96 \\
4\end{array}$ & 99 \\
\hline $\begin{array}{l}\text { Beta- } \\
\text { phellandrene }\end{array}$ & M & 24.54 & 7.015 & 91 & $\begin{array}{l}\text { Beta- } \\
\text { phellandrene }\end{array}$ & M & 1.57 & 9.763 & 91 & $\begin{array}{l}\text { Beta- } \\
\text { phellandrene }\end{array}$ & M & 1.36 & 9.773 & 91 \\
\hline (+)-4-carene & M & 1.21 & 8.777 & 98 & $(+)$-4-carene & M & 1.81 & 8.773 & 98 & (+)-4-carene & M & 2.88 & 8.782 & 96 \\
\hline Beta-myrcene & M & 1.42 & 8.144 & 96 & Beta-myrcene & M & 1.05 & 8.139 & 96 & $(+)$-4-carene & M & 2.44 & $\begin{array}{l}12.77 \\
3\end{array}$ & 98 \\
\hline D-limonene & M & 2.24 & 9.439 & 98 & D-limonene & M & 2.21 & 9.435 & 98 & D-limonene & M & 3.31 & 9.439 & 98 \\
\hline $\begin{array}{l}\text { Gamma- } \\
\text { terpinene }\end{array}$ & M & 1.99 & 11.206 & 97 & $\begin{array}{l}\text { Gamma- } \\
\text { terpinene }\end{array}$ & M & 3.18 & 11.206 & 97 & $\begin{array}{l}\text { Gamma- } \\
\text { terpinene }\end{array}$ & M & 3.86 & $\begin{array}{l}11.21 \\
5\end{array}$ & 97 \\
\hline $\begin{array}{l}\text { Beta- } \\
\text { phellandrene }\end{array}$ & M & 1.48 & 9.773 & 91 & $\begin{array}{l}\text { Bicyclo [3.1.1] } \\
\text { hexan-- } \\
\text { 4methylene-1-(1 } \\
\text { methylethyl)- }\end{array}$ & A & 14.58 & 7.001 & 96 & $\begin{array}{l}\text { Trans- } \\
\text { isoeugenol }\end{array}$ & PP & 1.17 & $\begin{array}{l}53.41 \\
6\end{array}$ & 98 \\
\hline o-Cymene & M & 1.28 & 12.130 & 97 & o-Cymene & M & 1.54 & 12.120 & 97 & alpha-terpineol & M & 19.99 & $\begin{array}{l}33.91 \\
6\end{array}$ & 90 \\
\hline alpha-terpineol & M & 1.23 & 33.859 & 86 & & & & & & Terpinen-4-ol & M & 14.42 & $\begin{array}{l}28.82 \\
0\end{array}$ & 97 \\
\hline Terpinen-4-ol & M & 9.48 & 28.806 & 97 & & & & & & Eugenol & PP & 2.71 & $\begin{array}{l}50.47 \\
8\end{array}$ & 98 \\
\hline Eugenol & PP & 1.01 & 50.478 & 98 & & & & & & $\begin{array}{l}2^{\prime}, 3^{\prime}, 4^{\prime} \text { 'Trimetho } \\
\text { xyacetophenon } \\
\text { e }\end{array}$ & M & 8.82 & $\begin{array}{l}57.29 \\
2\end{array}$ & 91 \\
\hline $\begin{array}{l}\text { 5-Isopropyl- } \\
2 \text { methylbicyclo } \\
{[3.1 .0] \text { hexan- }} \\
20 \text { ol }\end{array}$ & $\mathrm{s}$ & 2.24 & 21.287 & 98 & & & & & & $\begin{array}{l}\text { 1,3- } \\
\text { Benzodioxole, } \\
\text { 4-methoxy-6- } \\
\text { (2-propenyl) }\end{array}$ & M & 16.79 & $\begin{array}{l}52.03 \\
0\end{array}$ & 99 \\
\hline $\begin{array}{l}\text { Bicyclo } \\
\text { [3.1.0]hexan-2- } \\
\text { ol, 2-methyl-5- } \\
\text { (1- } \\
\text { methylethyl)-,(1. } \\
\text { alpha, } 2 \text { alpha, } \\
\text { 5-alpha) }\end{array}$ & $\mathrm{s}$ & 2.11 & 25.725 & 98 & & & & & & $\begin{array}{l}\text { Bicyclo [3.1.1] } \\
\text { hexan-4- } \\
\text { methylene-1-(1 } \\
\text { methylethyl)- }\end{array}$ & s & 1.13 & 6.992 & 96 \\
\hline Safrole & A & 3.6 & 42.906 & 98 & & & & & & & & & & \\
\hline Methyleugenol & PP & 1.13 & 48.273 & 98 & & & & & & & & & & \\
\hline $\begin{array}{l}\text { 1,3Benzodioxol } \\
\text { e,4methoxy-6- } \\
\text { (2-propenyl) }\end{array}$ & M & 21.08 & 52.035 & 99 & & & & & & & & & & \\
\hline
\end{tabular}

Description: 1 Component of GC-MS analysis, ${ }^{2} \mathrm{~S}=$ Sesquiterpenoids, $\mathrm{PP}=$ Phenilpropanoids, $\mathrm{A}=\mathrm{Alipatichs,} \mathrm{M}=$ Monoterpenoids, ${ }^{3}$ Concentration of component, ${ }^{4}$ Retention time, and ${ }^{5}$ Quality. 
were eight components of the essential oil chemical compounds found in the seeds, mace, and fruit flesh oils, i.e., Alpha-pinene, Beta-pinene, Myristicin, Betaphellandrene, (+)-4-carene, Beta-myrcene, Dlimonene, and Gamma-terpinene, whereeach component was at various concentrations in each part of the plant. The other chemical components of essential oils were only identified from certain parts of nutmeg fruits. The difference in components and its concentrations can be determined by several factors including plant types and analyzed plant parts (Figueiredo et al. 2008; Kizil et al. 2015).

The aroma of an essential oil is formed by all components that constitute the essential oil, both the major component and its minor (supporting) components. Significant differences of chemical components were found in essential oils between Ambon Forest nutmeg and Banda nutmeg. In Ambon Forest nutmeg, essential oil, the main chemical component is dominated by sesquiterpene compounds, while monoterpene compounds are more dominant in Banda nutmeg essential oil. The different chemical components and contents of essential oils in Ambon Forest nutmeg and Banda nutmeg cause the aroma produced from these two types of essential oils to be very different (Ma'mun 2013).

Data from the analysis of essential oil chemical component of Ambon Forest nutmeg were then processed to generate a heatmap profile as shown in Figure 3. Based on the heatmap profile, the chemical component of Ambon Forest nutmeg essential oil is divided into two groups: group 1 is the major component $A$ and group 2 is the minor component $B$. The main components of Ambon Forest nutmeg essential oil consisted of chemical compounds AlphaCubebene, Gama-unsure, Copaene, Beta-Copaene,
Caryophyllene, Humulene, Gama-Cadinene, Germacrene B, Aromandendrene, and Myristicin. Supporting components consisted of Germacrene D, Guaiol, Eugenol, Curcumene, and the other chemical compounds from the sesquiterpenoids group.

Based on the results of the heatmap analysis, the description of the highest concentration of compounds (it is characterized by green in the figure) was also obtained from each part of Ambon Forest nutmeg. These chemical compounds are sometimes only found in certain parts and not in the other parts. Chemical compounds with high concentrations in seed oil of Ambon Forest nutmeg were Caryophyllene, Humulene, Germacrene B, Beta-Copaene, Gama-elements, and Aromandendrene. Chemical compounds found in fruit flesh oil were Myristicin, D-Limonene, Betaphellandrene, O-Cymene, Linalool, 2-Undecanone, Alpha-Terpineol, Zingeberene, Beta-bisabolene, Tumerone, and 2(4a,8-Dimethyl-2,3,4,5,6,8ahexahydro-1H-naphthalen-2-yl) propa-2ol. Chemical compounds with high concentrations in mace oil were Beta-Curcumene, Cis-muurole-3,5-diene, Curzerane, Caryophyllene oxide, Neroidol, Naphthalene 1,2,3,4, 4a,7-hexahydro-1, 6-dimethyl-4-(1-methylethyl), Spathulenol, Gurjunene, Cis-Thujopsene, BetaElemenone, Germacrene D, Epicurzerenone, Cadinene, alpha-Patchoulene, and Ar-Turmerone.

The Heatmap analysis results also showed that there were major components that characterize the parts of the analyzed nutmeg fruits. The marker components in Banda nutmeg fruit flesh oil were DLimonene, Beta-phellandrene, Alpha-Terpineol, Alphapinene, Beta-pinene, (+)-4-carene, Myristicin, Gammaterpinene, Terpinen-4-ol, 2',3',4'Trimethoxyacetophenone, Trans-isoeugenol, Eugenol, 1,3-Benzodioxole- 4-methoxy-6-(2-propenyl), and

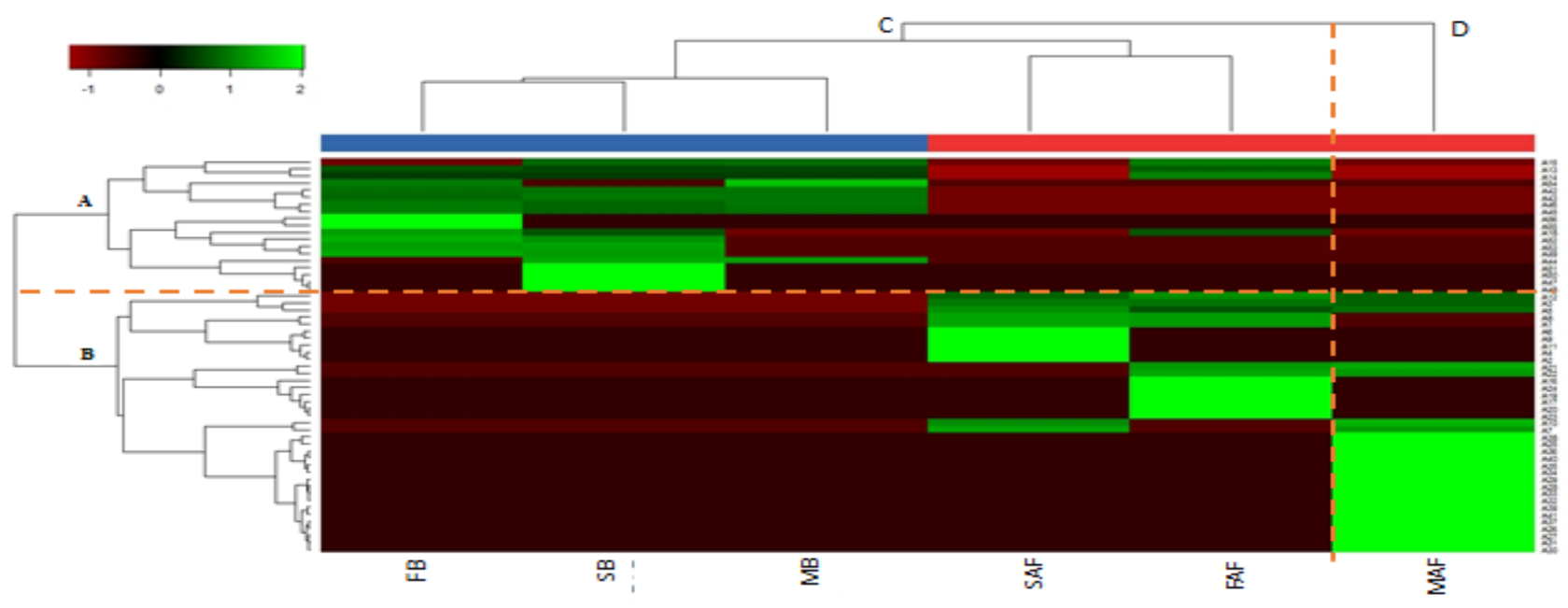

Figure 3 Heatmap grouping of essential oil components of Ambon forests nutmeg and Banda nutmeg. The main component $(A)$, supporting component $(B)$, oil from the analyzed part $(C, D)$; essential oil component (A1-56); Banda .nutmeg fruit flesh oil (FB), Banda nutmeg seeds oil (SB), Banda nutmeg mace oil (MB), Ambon Forest nutmeg seeds oil (SAF), Ambon Forest nutmeg fruit flesh oil (FAF), Ambon Forest nutmeg mace oil (MAF). 
Bicyclo [3.1.1] hexan-4-methylene-1-(1 methylethyl). In Banda nutmeg seeds oil, the marker components were O-Cymene, D-Limonene, Beta-phellandrene, Alphapinene, Beta-pinene, (+)-4-carene, Myristicin, Gammaterpinene, Beta-myrcene,Terpinen-4-ol, 2',3',4'Trimethoxyacetophenone, Safrole, Methyleugenol, Eugenol, 1,3-Benzodioxole-4-methoxy-6-(2-propenyl), 5-Isopropyl-2-methylbicyclo [3.1.0] hexan-20ol, Bicyclo [3.1.0]hexan-2-ol, and 2-methyl-5-(1-methylethyl)(1.alpha, 2 alpha, 5- alpha). The marker chemical compounds in Banda nutmeg mace oil were $\mathrm{O}$ Cymene, D-Limonene, Beta-phellandrene, Alphapinene, Beta-pinene, (+)-4-carene, Myristicin, Gammaterpinene,

Beta-myrcene, 2',3',4'Trimethoxyacetophenone, and Bicyclo [3.1.1] hexan-4-methylene-1-(1 methylethyl). The overall identified components in Banda nutmeg was dominated by the monoterpene group.

Myristicin compound is a marker compound that gives a distinctive aroma to nutmeg oils. Myristicin compound found in Banda nutmeg oil was also found in Ambon Forest nutmeg oil. Based on the analysis, the myristicin in Ambon Forest nutmeg oil was $1.3 \%$ in seeds, $1.16 \%$ in mace, and $5.19 \%$ in fruit flesh, while in Banda nutmeg it was $8.72 \%$ in seeds, $10.14 \%$ in mace, and $10.46 \%$ in fruit flesh (Figure 4). The myristicin contents of the three parts of Ambon Forest nutmeg were still lower compared to those of Banda nutmeg oil. The study of Jamal \& August (2004) showed different results, in which myristicin was not found in $M$. fatua Houtt nutmeg oil. The components of chemical compounds identified in Ambon Forest and Banda nutmeg essential oils were highly variable which showed the different components and concentrations. These differences were apparently due to the differences in plant types and the environment. The difference in the chemical components of essential oils is the result of secondary metabolites that are influenced by genetic, environmental, and ontogenetic factors (Figueiredo et al. 2008; Kizil et al. 2015).
Myristicin is a clear liquid, insoluble in water, but soluble in organic solvents. Myristicin has a distinctive smell like spices and the aroma is sharp and volatile. Its molecular weight is $192 \mathrm{~g} / \mathrm{mol}$ and its specific gravity is $1.1437 \mathrm{~g} / \mathrm{mol}$. The refractive index is 1.540 with a wavelength/max $\lambda$ of $278 \mathrm{~nm}$. The other names of myristicin are 5 allyl-1 methoxy-2,3 methylene dioxybenzene or 5 methoxy safrole. Myristicin is a volatile component that has a peculiar smell of nutmeg and has a great killing power against insect larvae and can increase mental activity or function as a psychoactive or psychotropic material (Kapelle \& Laratmasel 2014). Myristicin can act as a serotonin receptor agonist and contains hallucinogenic compounds which can be used as effective insecticide ingredients (Barceloux 2008).

\section{CONCLUSION}

The analytical results of essential oil contents showed that the seeds, mace, and fruit flesh of Ambon Forest nutmeg contained $0.63 \%, 0.30 \%$, and $0.04 \%$ essential oil, respectively, lower than Banda nutmeg essential oil content in the seeds $(1 \%)$, mace $(40 \%)$, and fruit flesh (3.5\%). The analytical results of the chemical composition of Ambon Forest nutmeg essential oil showed 12 identified compounds in nutmeg seeds oil, 24 compounds in mace oil, and 17 compounds in fruit flesh oil; while for Banda nutmeg, 18 compounds in the seeds, 10 compounds in the mace, and 15 compounds in the fruit flesh were identified. Ambon Forest nutmeg produced the chemical compound Copaene as the highest content compared to the other compounds, i.e., $28.41 \%$ in the seeds, $10.42 \%$ in mace, and $23.33 \%$ in fruit flesh. Myristicin compound which is the main marker compound and gives a distinctive aroma of nutmeg oil, was also found in Ambon Forest nutmeg with the contents of $1.30 \%$ in the seeds, $1.16 \%$ in mace, and $5.18 \%$ in fruit flesh, but these results were relatively low compared to Banda

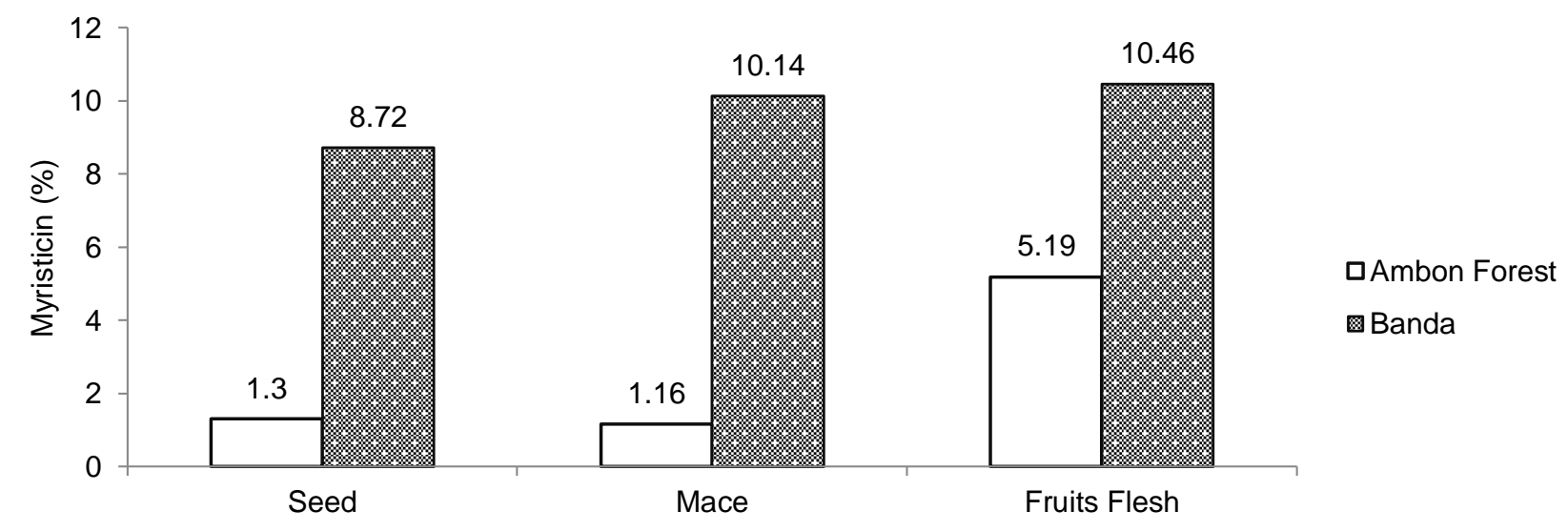

Nutmeg fruit part

Figure 4 Myristicin content (\%) in Ambon Forest nutmeg and Banda nutmeg. 
nutmeg with Myristicin contents in the seeds was $8.72 \%$, mace was $10.14 \%$, and fruit flesh was $10.46 \%$.

\section{REFERENCES}

Afoulous $S$, Ferhout $H$, Raoelison EG, Valentin A, Moukarzel B, Couderc F, Bouajila J. 2013. Chemical composition and anticancer, antiinflammatory, antioxidant and antimalarial activities of leaves essential oil of Cedrelopsis grevei. Food Chem Toxicol. 56: 352-362. https://doi.org/10.1016/j.fct.2013.02.008

Assagaf M, Hastuti P, Hidayat C, Supriyadi. 2012.Perbandingan ekstraksi oleoresin biji pala (Myrictica fragrans Houtt) asal Maluku Utara menggunakan metode maserasi dan gabungan distilasi-maserasi. Journal Agritech. 32(3): 240248.

Barceloux DG. 2008. Medical Toxicology of Natural Substances: Foods, Fungi, Medicinal Herbs, Toxic Plants, and Venomous Animals. New York (US): J Wiley.

De Wild WJJO. 2000. Myristicacea Series I-Seed Plant. Flora Malesiana Vol. 14. Nationaal Herbarium Nederland. Nederland (ND): Universiteit Leiden branch.

Fajriah S, Darmawan A, Megawati, Hudiyono S, Kosela S, Hanafi M. 2017. New cytotoxic compounds from Myristica fatua Houtt leaves against MCF-7 cell lines. Phytochem Letters. 20: 36-39. https:// doi.org/10.1016/j.phytol.2017.03.013

Fajriah S, Megawati. 2015. Phytochemical screening and toxicity assay from Myristica fatua Houtt leaves. Chimica et Natura Acta. 3(3): 116-119. https:// doi.org/10.24198/cna.v3.n3.9219

Figueiredo AC, Barroso JG, Pedro LG, Scheffer JJC. 2008. Factors affecting secondary metabolite production in plants: volatile components and essential oils. Flavour and Fragrance Journal. 23: 213-226. https://doi.org/10.1002/ffj.1875

Heyne. 1987. Tumbuhan Berguna Indonesia Vol 3. Jakarta (ID): Yayasan Sarana Wana Jaya.

Jamal, Agusta. 2004. Komposisi Kimia Minyak Astiri Pala Wegio (Myristica fatua Houtt). Berita Biologi. 7(3): 155-158.

Kapelle IBD, Laratmase MS. 2014. Trimyristin isolation from nutmeg and synthesis of methylester using heterogen catalyst. Indonesian Journal Of Chemical Research. 2: 160-165.

Ketaren S. 1987. Pengantar Teknologi Minyak Atsiri. Balai Pustaka. 458 pp.

Kizil S, Toncer O, Diraz E, Karaman S. 2015. Variations in essential oil rates and compositions characteristics and essential oil components of zahter (Thymbra spicatal. Var. Spicata) populations in semi-arid climatic conditions. Turkish journal of field crops. 20(2): 242-251. https://doi.org/10. $17557 /$ tjfc. 46517

Lim TK. 2012. Edibel Medicinal and Non-Medicinal Plants.Vol 3, Fruit. Springer, New York (US): Pp. 572-574. https://doi.org/10.1007/978-94-007-25348_79

Ma'mun. 2013. Characteristics of Oil and Trimyristin Isolation of Papua Nutmeg Seeds (Myristica argentea). Jurnal Littri. 19(2): 72-77.

Nishida R, Shelly TE, Whittier TS, Kaneshiro KY. 2000. a-Copaene, a potential rendezvous cue for the mediterranean fruit fly, Ceratitis capitata. Journal of Chemical Ecology. 26: 87-100. https://doi.org/10. 1023/A:1005489411397

Pal M, Srivastava M, Soni DK, Kumar A, Tewari SK. 2011. Composition and anti-mikrobial activity of essensial oil of Myristica fragrans from Andaman Nicobar Island. International Journal of Pharmaceutical and Life Science. 2(10): 11151117.

Quintans JS, Soares BM, Ferraz RP, Oliveira AC, da Silva TB, Menezes LR, Sampaio MF, Prata AP, Moraes MO, Pessoa C, Antoniolli AR, Costa EV, Bezerra DP. 2013. Chemical constituents and anticancer effects of the essential oil from leaves of Xylopia laevigata. Planta Med. 79: 123-130. https:// doi.org/10.1055/s-0032-1328091

Shafiq MI, Ahmed M, Rasul A, Samra ZQ, Qadir MA, Mazhar S, Ali A. 2016. Chemical Composition of the Essential Oils of Nutmeg and Mace by GC-FID/MS Indigenous to Pakistan and Evaluation of their Biological Activities. Latin American Journal of Pharmacy. 35(10): 2176-2184.

SNI. 2006. Minyak Pala. Standar Nasional Indonesia 06-2388. Jakarta (ID): Badan Standarisasi Nasional. $6 \mathrm{hlm}$.

Turkez H, Togar B, Celik K. 2013. Effects of copaene, a tricyclic sesquiterpene, on human lymphocytes cells in vitro. Cytotechnology. 66: 597-603. https:// doi.org/10.1007/s10616-013-9611-1

Turkez H, Togar B, Tatar A, Geyıkoglu F, Hacımuftuoglu A. 2014. Cytotoxic and cytogenetic effects of a-Copaene on Rat neuron and N2a neuroblastoma cell lines. Biologia. 69(7): 936-942, https://doi.org/10.2478/s11756-014-0393-5

Vinholes J, Rudnitskaya A, Goncalves P, Martel F, Coimbra MA, Rocha SM. 2013. Hepatoprotection of sesquiterpenoids: a quantitative structure-activity relationship (QSAR) approach. Food Chem.146: 78-84. https://doi.org/10.1016/j.foodchem.2013.09. 039 